\title{
Feeding activities of two euryhaline small-sized fish in a western Baltic brackish fjord
}

\author{
Birgit Antholz, Wolfgang Meyer-Antholz \& C. Dieter Zander \\ Zoologisches Institut und Zoologisches Museum der Universität Hamburg; \\ Martin-Luther-King-Platz 3, D-W-2000 Hamburg 13, Federal Republic of Germany
}

\begin{abstract}
The daily food intake and feeding activities of the common goby Pomatoschistus microps (Krøyer) and the nine-spined stickleback Pungitius pungitius (L.) were investigated in the brackish Schlei fjord. At the investigation site of Olpenitz, salinities varied between 11 and $15 \%$, and water temperatures between 5 and $18^{\circ} \mathrm{C}$ during the period of in-situ experiments in 1981 and 1982. Common gobies sometimes attained a density of more than 100 individuals per square metre, nine-spined sticklebacks as much as 18 individuals per square meter. Their food changed depending on the supply of plankton or benthos. Regarding numbers, their food consisted mainly of harpacticoids, in springtimes of calanoids; with regard to weight, amphipods, polychaetes or chironomid larvae often prevailed. The total food ingestion, measured by means of its relation to fish weights (fullness index), was highest in spring and summer: $2.3 \%$ in $P$. microps and $2.6 \%$ in $P$. pungitius. Low fullness indices of $0.8 \%$ in $P$. microps and $0.3 \%$ in $P$. pungitius were found during times of low water temperatures. 24 -h field investigations revealed that the adult $P$. microps presented clear diurnal rhythms with highest fullness indices after dawn and a further maximum at dusk. Only young gobies ingested some benthos at night. $P$. pungitius displayed similar rhythms in which maximum fullness indices varied during the day. This species seems to forage every four hours. At dusk, both species preferred benthos to plankton. The results are discussed with respect to the implications of diurnal and seasonal fluctuations in prey choice by small-sized fish populations.
\end{abstract}

\section{INTRODUCTION}

The common goby Pomatoschistus microps (Krøyer) and the nine-spined stickleback Pungitius pungitius (L.) are very abundant small-size fish in northern Europe. As they regularly migrate from marine to freshwater habitats and vice versa, they are generally found together in brackish waters also, e.g. in the Baltic Sea, or in freshwater, e.g. the upper Elbe estuary. Whereas the common goby reproduces in marine or brackish habitats, the stickleback prefers to spawn in freshwater.

The importance of small-sized fish in the aquatic ecosystem has recently been increasingly acknowledged (Miller, 1979; Jansson et al., 1985). Feeding studies involving the common goby or the nine-spined stickleback have considered mainly the food spectrum and its seasonality (Blegvad, 1917; Hynes, 1950; Healey, 1971; Zander, 1979b; Hennig \& Zander, 1981; Schmidt-Moser \& Westphal, 1981; Zander \& Hartwig, 1982), Swedish scientists have investigated the energy transfer and the feeding impact of Baltic common gobies on their communities (Evans, 1984; Evans \& Tallmark, 1984; Pihl, 1985) as well as the resource partitioning of gobies, sticklebacks and other fish species (Thorman \& Wiederholm, 1983, 1986). Even though Thorman \& Widerholm have already 
described the diurnal habitat preferences of five fish species, including $P$. microps and $P$. pungitius, in the eastern Baltic, results on 24-h feeding activities are still lacking.

The aim of the present study in a brackish Baltic fjord was to analyse the qualitative and quantitative composition of the prey of $P$. microps and $P$. pungitius during the day. These investigations may help, therefore, to clarify the role of small-sized fish within the food web and the community of shallow brackish habitats.

\section{INVESTIGATION SITE}

The Schlei fjord extends for about $40 \mathrm{~km}$ in a NE direction from the town of Schleswig to the Baltic Sea. Salinity increases from 0 to $20 \%$. The sampling site of Olpenitz lies near the mouth of the fjord (Fig. 1) where salinities of 12-19\% prevail

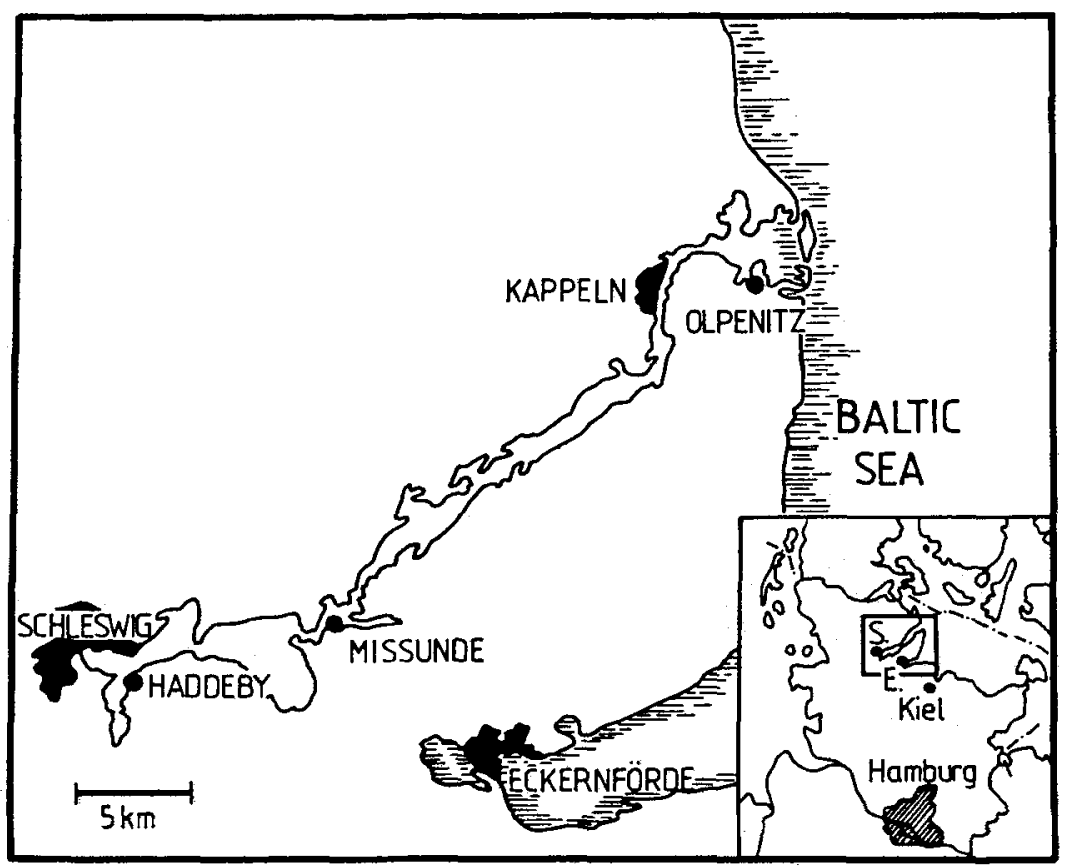

Fig. 1. Map of Schleswig-Holstein with details of the Schlei fjord and the investigation site at Olpenitz

(Pfannkuche, 1977). Fluctuations are caused by the different strengths and directions of winds. In the shallow coastal waters, the ground immediately below the water surface is covered with boulders and pebbles which favours the existence of the alga Fucus vesiculosus. This algal girdle borders on a medium-grained sand bottom (Pfannkuche, 1977).

\section{MATERIALS AND METHODS}

To study day-night activities, samples were taken at 7 dates in 1981 and 1982 . The fish were caught every $2 \mathrm{~h}$ throughout the day by means of a push net of $1.5 \mathrm{~mm}$ mesh 
size and an opening of $400 \times 400 \mathrm{~cm}^{2}$. The net was drawn over the shallow bottom until sufficient Pomatoschistus microps or Pungitius pungitius were caught. Not later than $30 \mathrm{~min}$ after the start, this procedure was ceased. In order to prevent regurgitation, the fish were narcotized and then fixed in $4 \%$ formalin. Every total and standard length was measured to the last $\mathrm{mm}$.

For analyses of feeding activities, 10 specimens of each species of nearly equal size were selected. These were dissected and their opened intestine tract emptied. The prey organisms found were assessed to relevant taxonomical units, counted, dried for several days at $60^{\circ} \mathrm{C}$, and thereafter weighed on a microscale to the nearest $\mu \mathrm{g}$. The fish were treated in the same way.

From these results the fullness index according to Hureau (1969) was calculated:

$$
\% \text { Full }=\frac{\text { Dry weight of prey } \times 100}{\text { Dry weight of fish }}
$$

Two parameters of the abiotic environment were measured: The temperatures were measured in-situ, the salinities in the laboratory by titrating the chloride ions.

The (peri-)phyton was sampled by means of a plastic pail which was shoved under the algae-thalli, then lifted above the water surface. The samples were fixed in $4 \%$ formalin. The organisms living on the algae were assessed to taxonomical units and counted. The algae were dried for one week at $60^{\circ} \mathrm{C}$ and weighed to the nearest $10 \mu \mathrm{g}$.

A plexiglass core with an opening of $10 \mathrm{~cm}^{2}$ was used to get benthos samples of which the upper $4-5 \mathrm{~cm}$ were fixed in $4 \%$ formalin, coloured with Bengal-pink, and elutriated. The fraction was retained by a sieve of $0.063 \mathrm{~mm}$ mesh size, assessed to taxonomical units, and counted.

Plankton was usually sampled three times during one investigation date: in the afternoon, at night, and in the morning. 501 water were poured each time through a net of $0.1 \mathrm{~mm}$ mesh size; the fraction was fixed in $4 \%$ formalin. The samples were assessed to higher taxonomical units and counted.

\section{RESULTS}

\section{Abiotic and biotic environment}

The water temperatures at the investigation site showed the fluctuations expected during the course of a year (Fig. 2a). The day-night changes were greater in spring than in summer and autumn. The salinity was highest in autumn at $15 \%$, obviously due to storms which cause more intensive exchange with the water bodies of the Belt Sea (Fig. 2a).

The abundance of the organisms from the Fucus-thalli (= phyton) is characterized by two countercurrent trends: In spring, amphipods and isopods prevailed but were later replaced by molluscs, especially Littorina saxatilis, and in late autumn by Mytilus edulis (Fig. 2b). Of the amphipods, Gammarus spp. appeared first, followed by Corophium insidiosum. With regard to the isopods, Jaera albifrons dominated, Idotea spp. or Sphaeroma sp. being present in lower abundances. Maximum numbers of phyton organisms were found in September (Fig. 2b). The psammon abundance, however, peaked as early as July. Harpacticoids and oligochaetes were the prevailing groups 


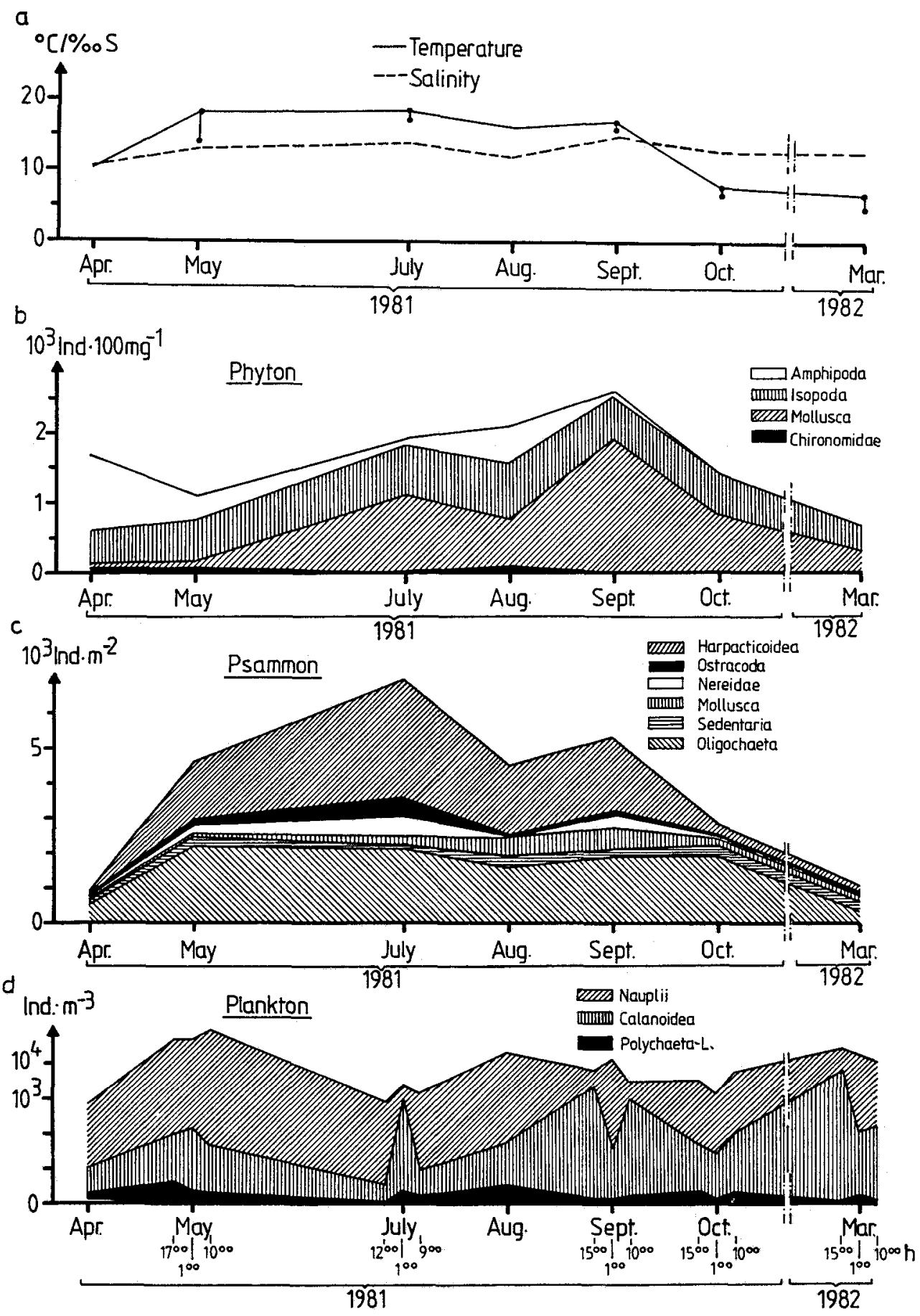

Fig. 2. Abiotic and biotic factors at Olpenitz in 1981 and 1982. a: Water temperature with day-night changes at 5 dates, and salinity. b: Phyton organism abundance. c: Psammon organism abundance. d: Plankton organism abundance; the total numbers are presented in a logarithmical scale but single components are related linearly at every date 
(Fig. 2c). Paranais litoralis was the most abundant of the oligochaetes species. The sedentarian polychaete Pygospio elegans was regularly found at all dates, whereas Polydora ciliata did not appear in remarkable quantities until September. The molluscs were represented by the snails, Littorina saxatilis and Hydrobia stagnorum, in autumn increasingly by young Mya arenaria and Cardium edule.

The plankton organisms attained maximum numbers in May and minimum values thereafter in July (Fig. 2d). The dominant organisms were calanoid copepods and their nauplii. Polychaete larvae were also regularly present. Other components such as cyclopoid copepods, cladocerans or mysids appeared only sporadically and in relatively low abundances. Calanoids and nauplii fluctuated in their relation during the day-night rhythm of a sample date. Whereas the nauplii dominated in July during night and the adult calanoids during day, this situation changed in autumn (Fig. 2d).

\section{Size distribution of gobies and sticklebacks}

In April 1981, one-year old common gobies of different sizes were present (Fig. 3). They grew very rapidly from April to May, their average sizes in these two months being 25 and $30 \mathrm{~mm}$, respectively. In May as well as in the following months, the gobies presented a more limited size distribution. Only ca 2-month old gobies were caught in July with a mean size of $19 \mathrm{~mm}$. These specimens grew until September to an average size of $25 \mathrm{~mm}$ (Fig. 3). The August sample of nine-spined sticklebacks also revealed a

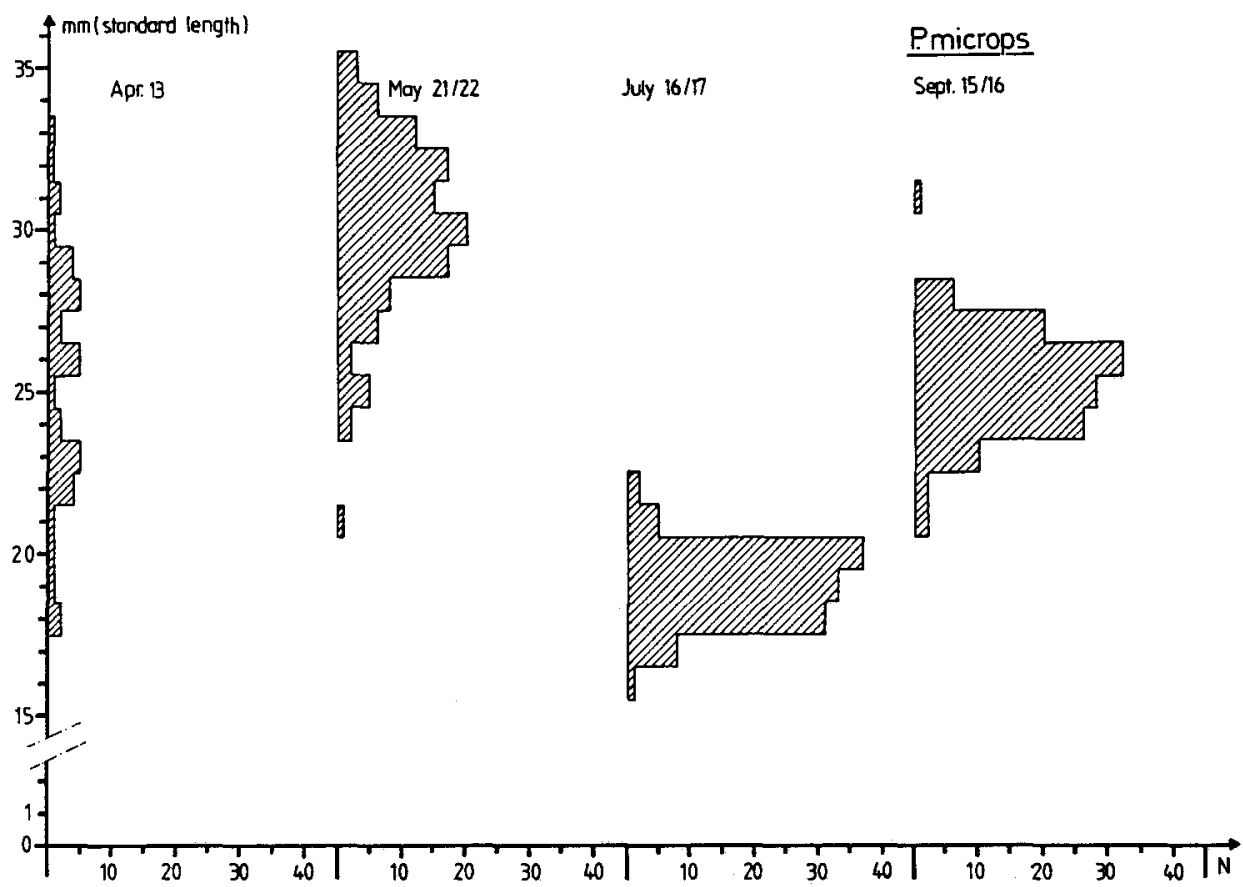

Fig. 3. Size distribution (standard length) of Pomatoschistus microps from 30-min catches at four dates in 1981 


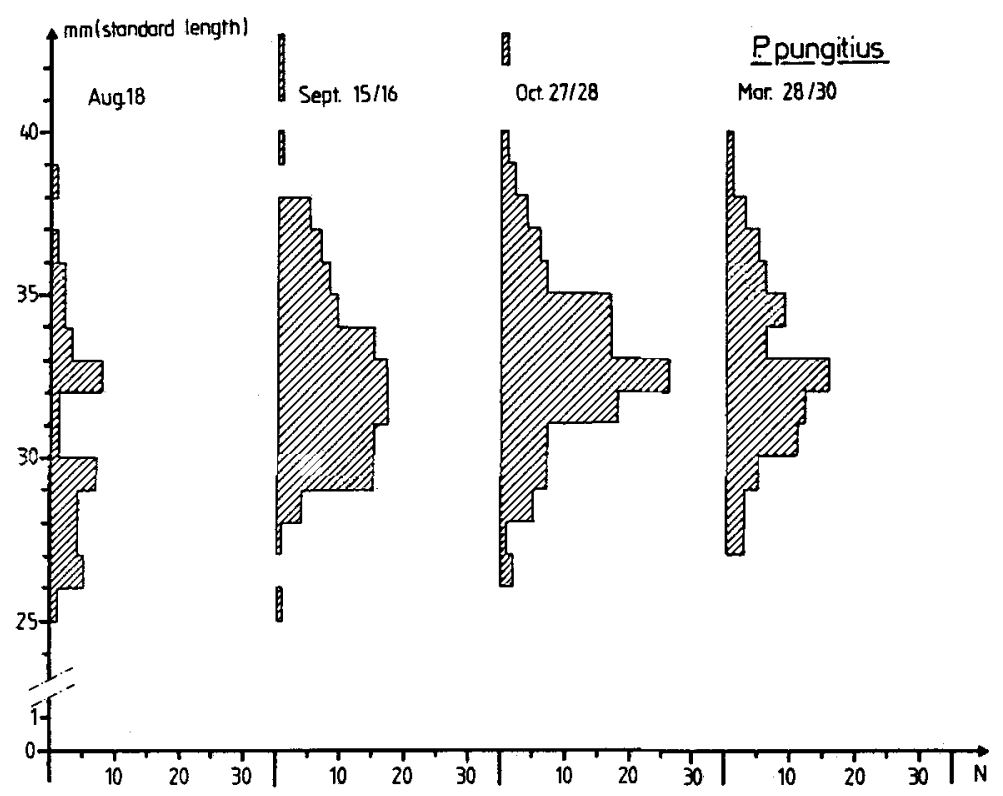

Fig. 4. Size distribution (standard length) of Pungitius pungitius from 30-min catches at three dates in 1981 and at one in March 1982

broad size range when the investigation of this species started (Fig. 4). The mean size, which was $30 \mathrm{~mm}$ in August, increased to $32 \mathrm{~mm}$ in September when some specimens also surpassed the $40 \mathrm{~mm}$ size. Size distribution and mean size of the October samples were similar to those of the month before. A very similar size distribution was also found in samples taken in March 1982.

\section{Fluctuation of fullness indices}

In spring 1981, as many as 113 common gobies Pomatoschistus microps were investigated (Fig. 5). The study began at $13.00 \mathrm{~h}$ when the highest values of fullness were found. Thereafter, feeding was probably interrupted since the values decreased rapidly until $17.00 \mathrm{~h}$. Ingestion increased again after dusk, but ceased during darkness. At dawn, feeding activity started again and continued until midday. In July, when 118 young common gobies were investigated, feeding activity was clearly visible every 4 hours (Fig. 5). It reached its maximum at dusk and was also present during the night.

The feeding activity of 133 larger young gobies caught in September presented almost constant ingestion rates until darkness (Fig. 5). At $23.30 \mathrm{~h}$, the food components seemed to be digested more completely than at $21.30 \mathrm{~h}$; therefore, no food might be ingested during the night. Feeding activity started again at dawn and culminated at $9.30 \mathrm{~h}$. The mean fullness indices were highest in May (2.3) and lowest in September (1.9), in July they were intermediate (2.1).

109 specimens of the stickleback Pungitius pungitius showed a distinct diurnal activity in September (Fig. 6). The mean fullness index was highest at the start of the 

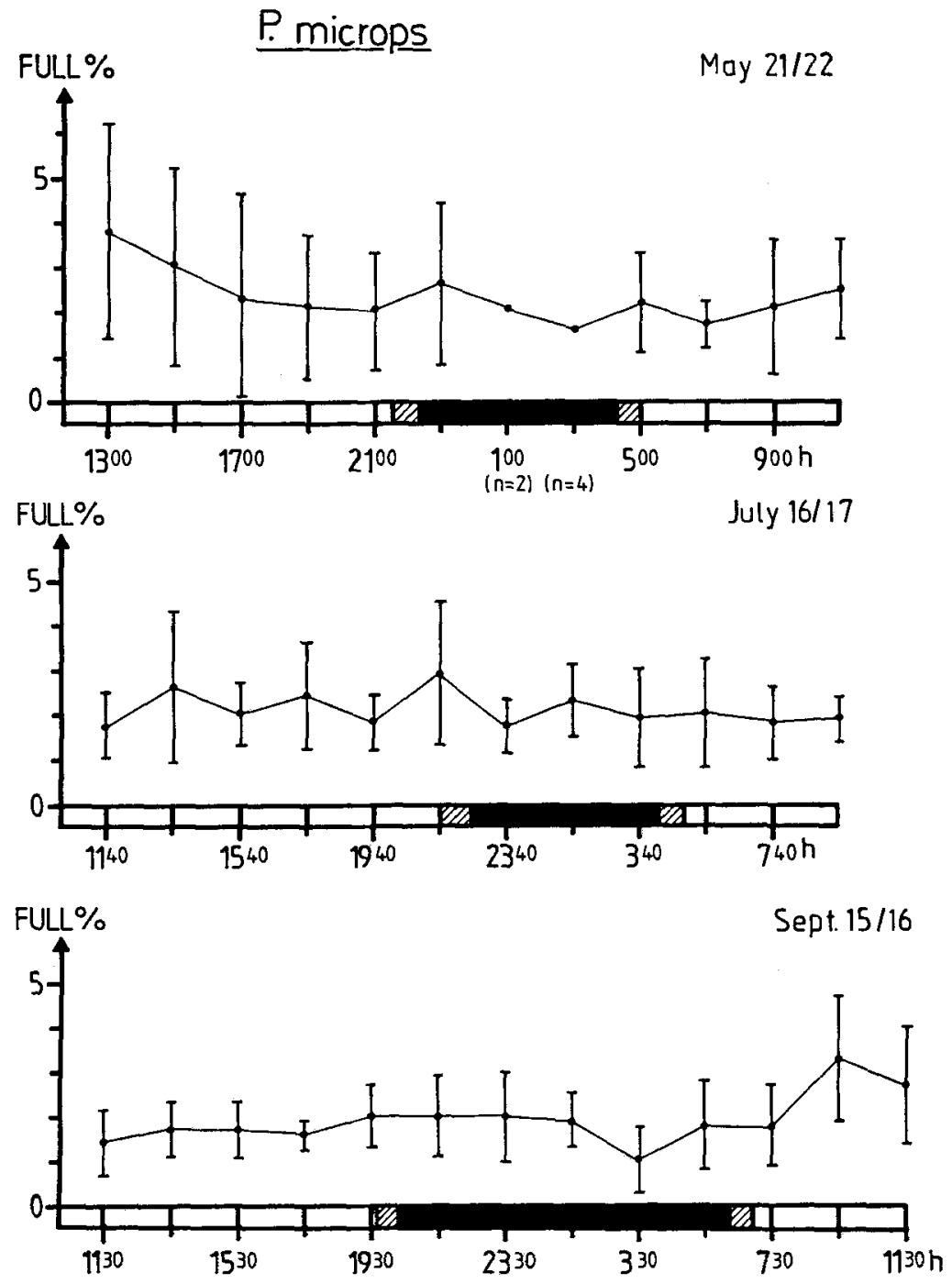

Fig. 5. Variations in the fullness indices of Pomatoschistus microps during the daily cycle at three dates in 1981

investigation at $10.30 \mathrm{~h}$ and remained nearly constant thereafter. A steep decrease was observed during darkness when feeding obviously ceased. At daybreak the activities started again and led gradually to high indices at $10.30 \mathrm{~h}$.

The fullness indices of 120 sticklebacks caught in October were clearly lower than in September. Higher values were found between $12.00 \mathrm{~h}$ and $22.00 \mathrm{~h}$. Thereafter, they dropped to nearly zero. Only a slight increase was found after daybreak.

In March, the indices found in 83 sticklebacks were higher than in October. A maximum at $15.30 \mathrm{~h}$ was followed by a decrease and a new increase until $21.30 \mathrm{~h}$, two 

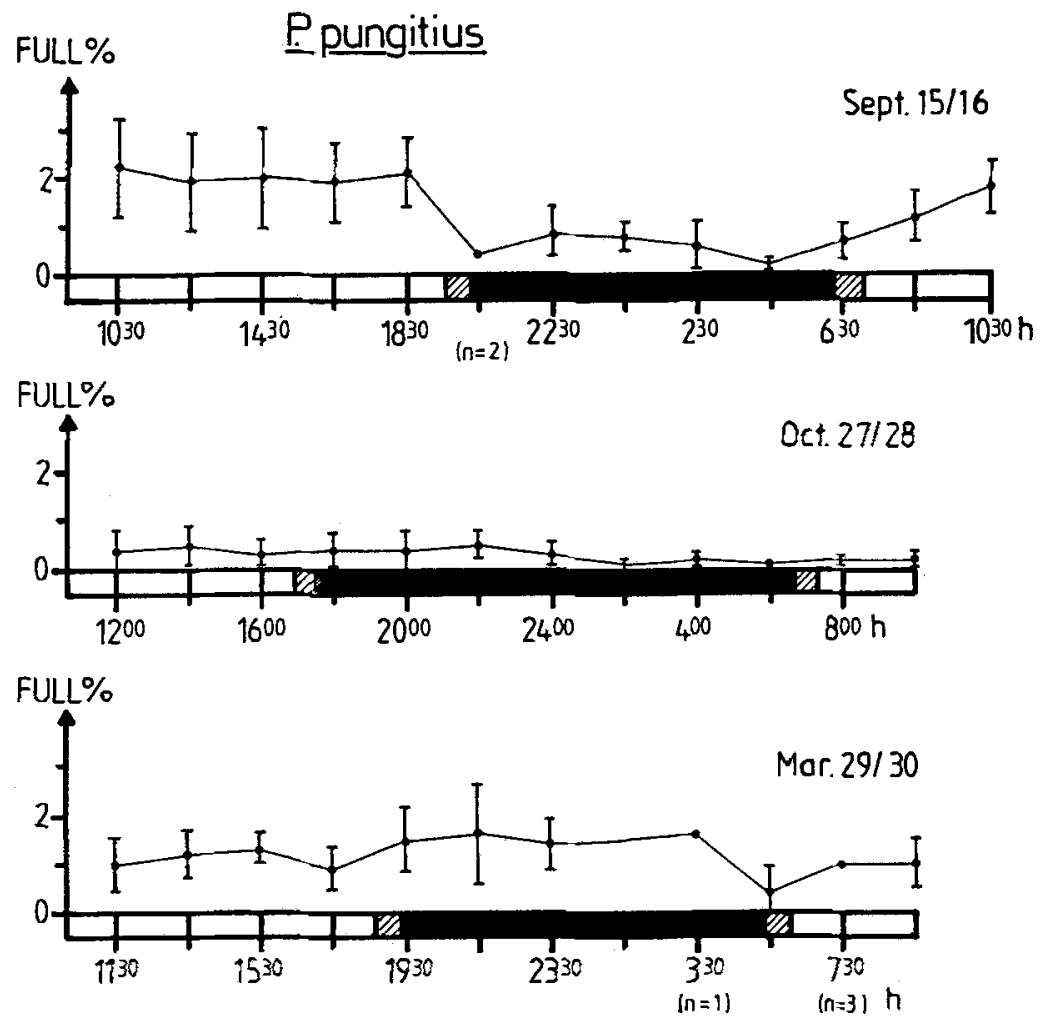

Fig. 6. Variations in the fullness indices of Pungitius pungitius during the daily cycle at two dates in 1981 and at one date in March 1982

hours after dusk. The lowest values were observed at daybreak when feeding activity started again.

The mean fullness indices were 1.3 in September, 1.1 in March and only 0.3 in October. A preliminary study of 40 sticklebacks in August resulted in 2.6.

\section{Fluctuation of ingested prey components}

\section{Pomatoschistus microps}

The samples of common gobies in May showed clear diurnal rhythms regarding the calanoids, polychaetes and amphipods ingested (Fig. 7a). At midday, calanoids dominated as ingested taxon by far but decreased thereafter until the next morning when their numbers increased again. Amphipods and sedentarian polychaetes showed a similar trend since their abundance was lower at night than at day. After daybreak, the increase in these ingested components clearly demonstrate that feeding activity had begun.

Oligochaetes and especially nereids were fed on to a greater extent at dusk (Fig. $7 \mathrm{a}$ ), leading therefore to the increase of the fullness indices at the beginning of darkness (see Fig. 5). In contrast, no clear diurnal rhythm was found in the goby samples from July (Fig. 7b). However, the highest number of food items was present at noon and afternoon. 

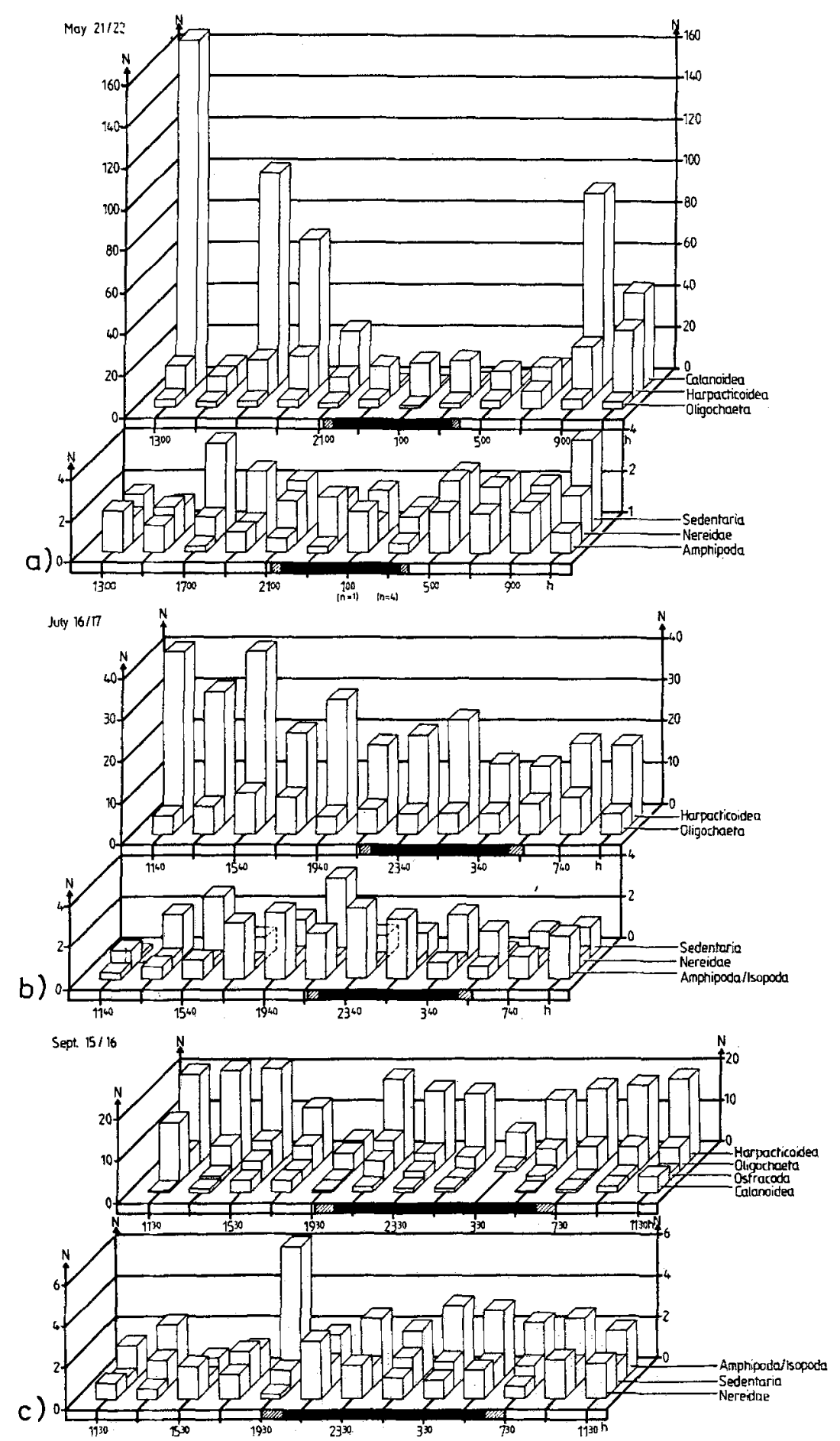

Fig. 7. Mean numbers of different food components ingested by Pomatoschistus microps during the daily cycle. The scale of numbers is differentiated with respect to meio- or macrofauna. Time scale: blank = daylight, hatched $=$ daybreak or dusk, black = night. a: May 1981 (6 food components); b: July 1981 (5 food components); c: September 1981 ( 7 food components) 
Sedentarian polychaetes were mostly ingested at dusk whereas the number of ingested harpacticoids, amphipods and isopods increased during night.

The September samples were remarkable because the amphipods and isopods ingested appeared in relatively high numbers but other components in low numbers (Fig. 7c). The abundance of harpacticoids and nereids obviously increased after darkness. Nevertheless, smaller components such as harpacticoids, ostracods or calanoids prevailed during the day whereas macrofauna prevailed at night. This led to almost identical fullness indices during the whole investigation time (see Fig. 5).

\section{Pungitius pungitius}

The September samples presented a stop of feeding during the night on all species except on harpacticoids and isopods (Fig. 8a). These two components also prevailed as ingested food in daytime, with the addition, however, of amphipods and chironomid larvae. Ostracods appeared only sporadically at day as well as at night. In contrast, feeding did not cease during night in the October samples (Fig. 8b). The abundances of harpacticoids, ostracods and especially chironomid larvae even increased after dusk but thereafter continuously decreased until daybreak.

In the samples from March, feeding activity was highest at dusk and ceased thereafter until the next morning (Fig. 8c). The situation at dawn was similar to that at midnight. In the morning, the numbers of calanoids ingested increased again whereas those of harpacticoids dropped.

\section{DISCUSSION}

The present investigations revealed that Pomatoschistus microps is day active in two out of three seasonal samples, and Pungitius pungitius in all three samples. Blegvad (1917) found clear diurnal rhythms in gobies and sticklebacks as their stomachs were filled until $22 \mathrm{~h}$ and thereafter emptied until morning. The feeding activities found in the present investigations are characteristic of many fish species. Peaks at dawn and at dusk show a light-dependent course. This result is confirmed by investigations of Casabianca \& Kiener (1969) on P. microps, Hesthagen $(1976,1980)$ on Gobius niger and Pomatoschistus pictus, Manzer (1976) on Gasterosteus aculeatus, and Worgan \& Fitzgerald (1981) on three sympatric sticklebacks. The painted goby, $P$. pictus, revealed decreasing activity below an illumination value of $4.5 \mathrm{lux}$, and a total stop at 0.2 lux (Hesthagen, 1980). The latter value is present in nights when there is a full moon. This value may in some nights be exceeded, which could explain Blegvad's (1917) results on Gobius niger which presented similarly filled stomachs during day and night in July, but it cannot explain the present July results because the night of investigation was very cloudy. It is more probable that the young common gobies caught at this date have higher digestion rates than adults. A similar result was also gained for young P. pictus (Zander, 1979a). Obviously, the young gobies ingest food every 4 hours. This thythm may be induced by the fullness ratio of the stomachs whereby food uptake takes place when the ingested food falls below a certain level. This phenomenon was also observed in $P$. microps by Casabianca \& Kiener (1969) and Hoffmann (1973).

Feeding is combined with activity rhythms, as Fonds \& Feldhuis (1973) and Tolksdorf (1977) found in $P$. microps. These authors demonstrated highest oxygen consumption at times of maximum feeding, and decreasing oxygen consumption during night-time. The 
a)
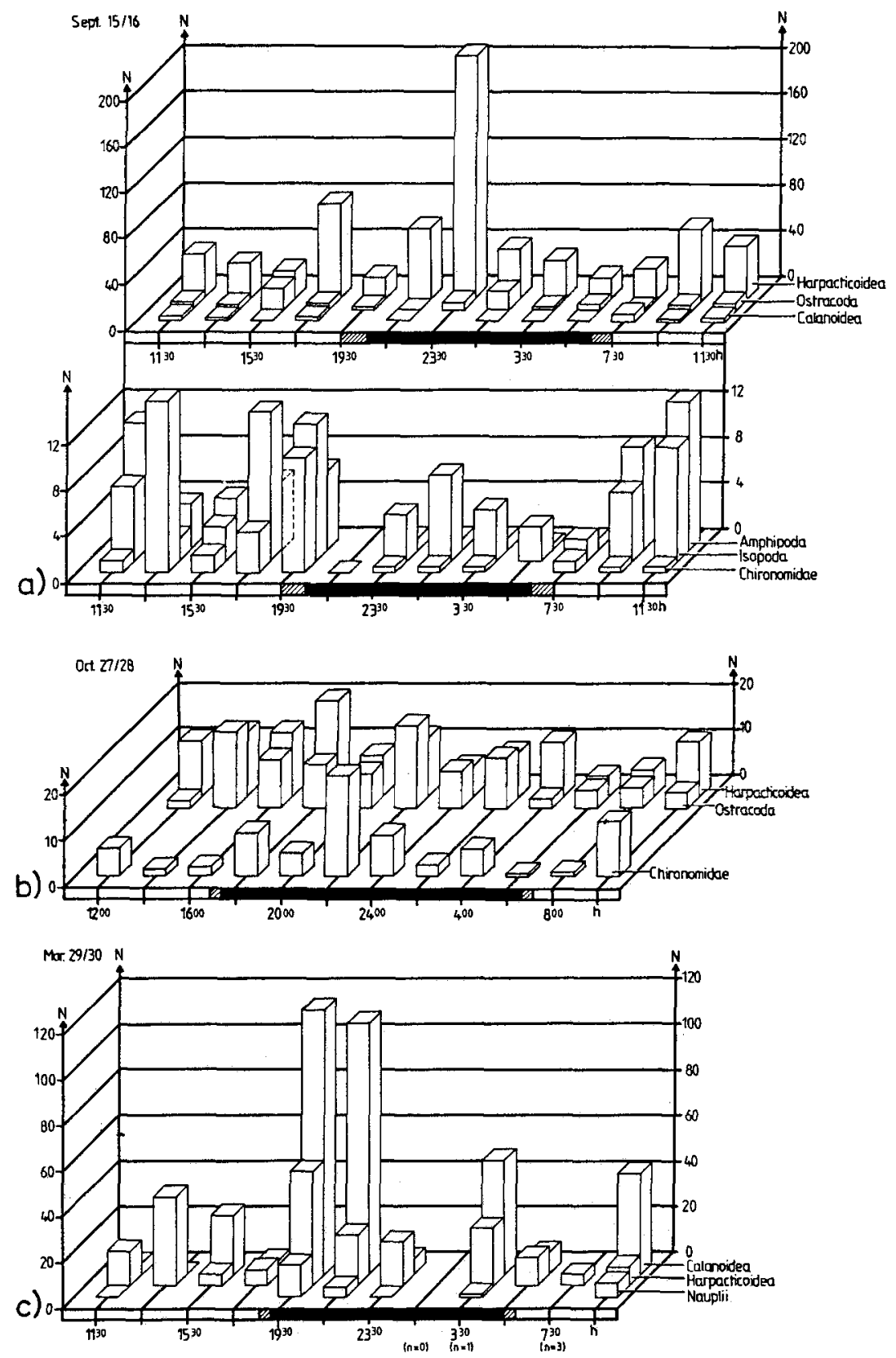

Fig. 8. Mean numbers of different food components ingested by Pungitius pungitius during the daily cycle. The scale of numbers is differentiated with respect to meio- and macrofauna. Time scale: blank $=$ daylight; hatched $=$ daybreak or dusk; black $=$ night. a: September 1981 (6 food components); b: October 1981 ( 3 food components); c: March 1982 ( 3 food components) 
influence of water temperature on feeding activities was found only in $P$. pungitius. In March at $8^{\circ} \mathrm{C}$ water temperature, the fullness ratios were lower than in September at $16^{\circ} \mathrm{C}$ water temperature. Lowest fullness indices were found in October with similar water temperatures as in March but better food supply. This phenomenon was also described by Hynes (1950), and may be due to low water temperature as well as decreasing light intensities.

Obviously, the ingested prey components changed during the course of 24 hours. Plankton was fed on by common gobies almost only at day which is clearly demonstrated by the amount of calanoids ingested. As gobies search for their prey especially by sight (Zander, 1979b; Hesthagen, 1980), foraging in the pelagial zone at dusk becomes increasingly difficult. Therefore, in this period benthic organisms like oligochaetes, harpacticoids, ostracods and polychaetes are ingested in greater numbers. Hoffmann (1973) found higher numbers of ingested oligochaetes at daybreak and dusk. Nereids are more active in dim light (Zunck, pers. comm.), and are ingested in greater numbers at daybreak and dusk. However, the number of amphipods and isopods ingested did not seem to decrease at night. According to Windell (1978), the chitine integument of these crustaceans, especially of Idotea and Sphaeroma, leads to longer stays in stomachs than is the case in other organisms. The plankton-foraging Gobiusculus flavescens, too, needs more time to digest harpacticoids (Microsetella) than other plankton organisms (Berg, 1979).

The feeding activity of $P$. pungitius was highest at dusk. Hesthagen (1976) assumed that this increase of ingestion in day-active fish is advantageous because prey as well as potential predators are still visible. Nevertheless, the most harpacticoids were fed on immediately after dusk as was found by Hesthagen (1973). This is obviously due to the greater availability of benthic organisms at this time. However, ostracods were ingested to a high degree at night because they move slowly and, therefore, might be caught more easily than other organisms. Also, the number of isopods ingested in the September samples increased during the night as observed in $P$. microps. This may be explained, however, by a slower digestion of thick integuments (Windell, 1978); occasional feeding in the night even by day-active fish cannot be excluded (Keast \& Welsh, 1968; Eriksson, 1978; Weisberg et al. 1981). No calanoids and nauplii were preyed upon during night as was already observed in $P$. microps. This means that $P$. pungitius also forages mainly by sight.

When the food spectra at different seasons are compared, $P$. microps preferred epibenthic organisms, whereby harpacticoids dominate in number, and isopods, amphipods and polychaetes in weight. $P$. pungitius, however, preferred epibenthic organisms in autumn but plankton in March. The preferred prey of $P$. pungitius was less homogenous than that of the common goby, as observed already in these species in the entire Baltic Sea (Zander, 1979b). Remarkably, oligochaetes played no role in the diet of the sticklebacks but in that of the common gobies. Regarding chironomids, the inverse situation is valid as is the case for specimens from the entire Baltic Sea (Zander, 1979b). Strong seasonal fluctuations of the prey in $P$. pungitius from the Swedish coasts were reported by Thorman \& Wiederholm (1983), whereas $P$. microps presented more homogenous feeding. An analysis of these two species from the Schlei fjord revealed that common gobies apparently switch to plankton in spring (Zander \& Westphal, 1991). The quantities of the supplied prey seem to be correlated with the numbers of ingested prey. 
In spring when plankton attained maximum values, calanoids especially were fed on by $P$. microps (May) and P. pungitius (March). The psammon components peaked in July just at a time when the most harpacticoids were ingested. The highest numbers of amphipods and isopods were ingested by both species in September when maximum numbers of phyton organisms were available. This high ingestion rate did not influence the abundance of supplied components by means of a grazing effect, as it was found in 1978 at the same site when harpacticoids were strongly influenced by $P$. microps (Schmidt-Moser \& Westphal, 1981). Zander \& Hagemann (1987) reported that sand gobies Pomatoschistus minutus from the western Baltic Sea ingested $78 \%$ of the harpacticoid production but only $12 \%$ of the gammarid and $6 \%$ of the Idotea production.

The present results of investigations carried out throughout the daily cycle as well as at three different seasons indicate that $P$. microps and $P$. pungitius are very opportunistic feeders. They preferred components which were present in sufficient quantities and were easily available. This is in accordance with results of Blegvad (1917), Hynes (1950), Zander (1979b), Schmidt-Moser \& Westphal (1981), Thorman \& Wiederholm $(1983,1986)$ and Zander \& Westphal (1991). Therefore, these two species are able to switch from macro- to meiobenthos, from epi- to suprabenthic organisms and vice versa, depending on their respective needs. Only plankton organisms are of minor importance at night because the fish are unable to detect them. This ability to feed opportunistically may be one of the reasons for the high population densities and successful existence of these two fish species.

Acknowledgements. We thank H.-D. Totzke and D. Westphal for help during the field investigations, and $M$. Hänel who drew the figures.

\section{LITERATURE CITED}

Berg, J., 1979. Discussions of methods of investigating the food of fishes, with reference to a preliminary study of the prey of Gobiusculus flavescens (Gobiidae). - Mar. Biol. 50, 263-273.

Blegvad, H., 1917. On the food of fish in the Danish waters within the skaw. - Rep. Dan. biol. Stn 24, $17-72$.

Casabianca, M.-L. de \& Kiener, A., 1969. Gobiidés des étangs Corses: Systématique, écologie, régime alimentaire et position dans les chaînes trophiques. - Vie Milieu 20A, 611-635.

Eriksson, L.-O., 1978. Nocturnalism versus diurnalism - Dualism within fish individuals. In: Rhythmic activity of fishes. Ed. by J. E. Thorpe. Acad. Press, London, 69-89.

Evans, S., 1984. Energy budgets and predation impact of dominant epibenthic carnivores on a shallow bottom community at the Swedish west coast. - Estuar. coast. Shelf Sci. 18,651-672.

Evans, S. \& Tallmark, B., 1984. Seasonal dynamics of small vagile predators on a marine shallow soft bottom. - Holarct. Ecol. 7, 138-148.

Fonds, M. \& Veldhuis, C., 1973. The oxygen consumption of four Pomatoschistus species (Pisces, Gobiidae) in relation to water temperature. - Neth. J. Sea Res. 7, 376-386.

Healey, M. C., 1971. The distribution and abundance of sand gobies, Gobius minutus, in the Ythan estuary. - J. Zool., Lond. 163, 177-229.

Hennig, R. \& Zander, C. D., 1981. Zur Biologie und Nahrung von Kleinfischen des Nord- und Ostseebereiches. III. Die Besiedlung eines Süßwasserwatts der Elbe durch euryhaline Fische. Arch. Hydrobiol. (Suppl.) 43, 487-505.

Hesthagen, I. H., 1973. Diurnal and seasonal variations in the near-bottom fauna - the hyperbenthos - in one of the deeper channels of the Kieler Bucht (Western Baltic). - Kieler Meeresforsch. 29, 116-140. 
Hesthagen, I. H., 1976. Locomotor activity of the black goby, Gobius niger L. (Pisces, Gobiidae), under artificial light conditions, including a false dawn and dusk. - Sarsia 62, 9-18.

Hesthagen, I. H., 1980. Locomotor activity in the painted goby, Pomatoschistus pictus (Malm) (Pisces), in relation to light intensity. - Sarsia 65, 13-18.

Hoffmann, H., 1973. Nahrungsuntersuchungen an Pomatoschistus microps Krøyer (Gobiidae, Perciformes, Teleostei) in Strandgewässern der westlichen Ostsee. Hausarbeit Lehramt Gymnasien, Univ. Kiel, $77 \mathrm{pp}$.

Hureau, J. C., 1969. Biologie comparée de quelques poissons antarctiques (Nototheneidae). - Bull. Inst. océanogr. Monaco 68, 1-131.

Hynes, H. B. N., 1950. The food of fresh-water sticklebacks, Gasterosteus aculeatus and Pygosteus pungitius with a review of methods used in studies of the food of fishes. - J. Anim. Ecol. 19, 36-58.

Jansson, B.-O., Aneer, G. \& Nellbring, S., 1985. Spatial and temporal distribution of the demersal fish fauna in a Baltic archipelago as estimated by SCUBA census. - Mar. Ecol: Prog. Ser. 23, $31-43$.

Keast, A. \& Welsh, L., 1968. Daily feeding periodicities, food uptake rates and dietary changes with hour of day in some lake fishes. - J. Fish. Res. Bd Can. 25, 1133-1144.

Manzer, J. I., 1976. Distribution, food and feeding of the threespined stickleback, Gasterosteus aculeatus, in Great Central Lake, Vancouver Island, with comments on competition for food with juvenile sockeye salmon (Oncorhynchus nerka). - Fish Bull., U.S. 74, 647-668.

Miller, P. J., 1979. Adaptiveness and implications of small size in teleosts. - Symp. zool. Soc. Lond. $44,263-306$.

Pfannkuche, O., 1977. Ökologische und systematische Untersuchungen an naidomorphen Oligochaeten der Schlei. Dipl.Arb., Univ. Hamburg, 65 pp.

Pihl, L., 1985. Food selection and consumption of mobile epibenthic fauna in shallow marine areas. Mar. Ecol. Prog. Ser. 22, 169-179.

Schmidt-Moser, R. \& Westphal, D., 1981. Predation of Pomatoschistus microps Krøyer and P. minutus Pallas (Gobiidae, Pisces) on macro- and meiofauna in the brackish fjord Schlei. - Kieler Meeresforsch. Sonderh. 5, 471-478.

Thorman, S. \& Wiederholm, A.-M., 1983. Seasonal occurrence and food resource use of an assemblage of nearshore fish species in the Bothnian Sea, Sweden. - Mar. Ecol. Prog. Ser. 10, 223 2229.

Thorman, S. \& Wiederholm, A.-M., 1986. Food, habitat and time niches in a coastal fish species assemblage in a brackish water bay in the Bothnian Sea, Sweden. - J. exp. mar. Biol. Ecol, 95, $67-86$.

Tolksdorf, W., 1977. Der Einfluß von Salzgehalt und Temperatur auf Wachstum, Stoffwechsel und Lethaltemperatur der Strandgrundel Pomatoschistus microps K. - Meeresforsch. 26, 15-29.

Weisberg, S. B., Whalen, R. \& Lotrich, V. A., 1981. Tidal and diurnal influence on food consumption of a salt marsh killifish Fundulus heteroclitus. - Mar. Biol. 61, 243-246.

Windell, J. T., 1978. Digestion and the daily ration of fishes. In: Ecology of freshwater fish productions. Ed. by S. D. Gerking. Blackwell, Oxford, 151-173.

Worgan, J. P. \& Fitzgerald, G. J., 1981. Diel activity and diet of three sympatric sticklebacks in tidal salt marsh pools. - Can. J, Zool. 59, 2375-2379.

Zander, C. D., 1979a. On the biology of small-sized fish from the North and Baltic Sea area. I. Investigations on Pomatoschistus pictus (Malm) (Gobiidae) from Helgoland. - Zool. Anz. 202, 413-424.

Zander, C. D., 1979b. On the biology of small-sized fish from the North and Baltic Sea area. II. Investigations of a shallow stony ground off Møn, Denmark. - Ophelia 18, 179-190.

Zander, C. D. \& Hagemann, T., 1987. Predation impact and ecological efficiency of Pomatoschistus ssp. (Gobiidae, Pisces). - Zool. Anz. 218, 33-48.

Zander, C. D. \& Hartwig, E., 1982. On the biology and food of small-sized fish from the North and Baltic Sea areas. IV. Investigations on an eulittoral mud flat at Sylt Island. - Helgoländer Meeresunters. 35, 47-63.

Zander, C. D. \& Westphal, D., 1991. Nahrungsbeziehungen von vier euryhalinen Kleinfischarten der Ostseeförde Schlei. - Zool. Jb. (Syst. Ökol. Geogr. Tiere) (in press). 